\title{
Morphological and ultrastructural studies on Ulva flexuosa subsp. pilifera (Chlorophyta) from Poland
}

\author{
Beata Messyasz1, Joanna Czerwik-Marcinkowska*, Andrzej Massalski², Bohuslav Uher ${ }^{2}$, Andrzej Rybak , Lidia \\ Szendzina', Marta Pikosz'1 \\ ${ }^{1}$ Institute of Environmental Biology, Adam Mickiewicz University, Umultowska 89, 61-614 Poznań, Poland \\ ${ }^{2}$ Institute of Biology, The Jan Kochanowski University in Kielce, Świetokrzyska 15, 25-406 Kielce, Poland \\ ${ }^{3}$ Department of Botany and Zoology, Masaryk University, Kotlářská 2, 61137 Brno, Czech Republic
}

\begin{abstract}
Ulva flexuosa subsp. pilifera (Kütz.) M. J. Wynne 2005 (= Enteromorpha pilifera Kützing 1845) was previously found in Argentina, the Czech Republic, Germany, Hungary, Romania, Slovakia and Sweden, recently also in Poland. The genus Ulva was first time described as Enteromorpha. Interestingly, Enteromorpha is used nowadays as a synonym for Ulva, a development which is based on molecular data. The morphologies of both young and mature specimens were studied, and most life cycle stages could be observed. Further, the formation of calcium carbonate crystals on the surface of Ulva thalli seems to influence the arrangement of the cells. A detailed ultrastructural (TEM) analysis of cell walls is presented. The TEM reveals in great details highly complex, irregular structures with stratification lines.
\end{abstract}

Keywords: green algae, ultrastructure, cell wall, Ulva flexuosa subsp. pilifera, Poland

\section{Introduction}

The genus Ulva is a representative of the family Ulvaceae and has the following characteristics: $(i)$ macroscopic, filamentous, thread-like, membranous (sheet-like); (ii) reproduction by biflagellate or quadriflagellate gametes or zoospores; (iii) multilayered cell walls are thick and made of microfibrils, which are usually irregularly arranged; (iv) each cell contains one parietal and cup-shaped chloroplast with one or several pyrenoids; $(\boldsymbol{v})$ a widely distributed marine genus with its few freshwater representatives [1,2]. Many species are adapted to wide ranges of habitats, with variable parameters such as salinity, temperature, water quality, and grow successfully in nutrient-rich habitats causing green tides and marine fouling $[3,4]$. Ulva species usually grow in form of typical vividly green tube- or leaf-shaped thalli, often also with various types of branches, attached to the substrate by rhizoids, or later as free-floating intestinoid clusters [5]. During its life cycle, Ulva forms morphologically similar haploid and diploid thalli, both of which produce asexual zoospores by mitotic division of

* Corresponding author. Email: marcinko@kielce.com.pl

Handling Editor: Andrzej Bodył

This is an Open Access digital version of the article distributed under the terms of the Creative Commons Attribution 3.0 License (creativecommons.org/licenses/by/3.0/), which permits redistribution, commercial and non-commercial, provided that the article is properly cited. vegetative cells [1]. Ulva flexuosa, taxonomically complicated macroalgal species, is distributed in coastal seawaters nearly worldwide [5]. According to Mareš [5] this species has many different morphological forms, and several important unifying characteristics: branching, cell structure, and chloroplast structure.

Ulva (syn. Enteromorpha) flexuosa subsp. pilifera (Kütz.) M. J. Wynne 2005 (= Enteromorpha pilifera Kützing 1856) has been observed at four sampling sites in Poland [6-10]. In studies reported from around the world, Ulva flexuosa subsp. pilifera has been identified in many inland sampling sites, namely in Sweden [11], Slovakia and the Czech Republic [12,13], Argentina [14], in England [15], Germany and Hungary [13].

According to the current knowledge, freshwater Ulva, including $U$. flexuosa subsp. pilifera [8,10-13], appear only as monostromatic tubular or sometimes leaf-like thalli (e.g. $U$. intestinalis, $U$. compressa, $U$. flexuosa). This makes a major difference from the marine Ulva, which frequently grow also in form of distromatic frondose thalli. The thallus of Ulva flexuosa subsp. pilifera can reach a length of up to $1 \mathrm{~m}$, and it is poorly branched but has numerous proliferations. According to Starmach [12] and Pliński [16], cells of this species are rectangular rounded $(22-30 \times 12 \mu \mathrm{m})$ or sometimes polygonal rounded, and are arranged in longitudinal and crosswise rows. Chloroplasts are parietal, girdle-shaped, covering most of the cell wall, with 2 (rarely 4 ) pyrenoids occur in a cell. The zoospores are about $10 \mu \mathrm{m}$ long and $5 \mu \mathrm{m}$ wide in diameter. Male gametes $(6.3 \times 2.7 \mu \mathrm{m})$ are slightly smaller than female gametes $(6.7 \times 3.4 \mu \mathrm{m})$. It is generally known that gametes can germinate without the fertilization process. The number of pyrenoids can change during the lifespan of thalli, pyrenoids 
may be numerous in the autospores but less numerous in the mature cells. However, as Griffiths [17] suggested, it is difficult to correlate the presence or absence of pyrenoids with any of other major diacritical features.

In the 1970's, ultrastructural studies led to a reclassification of this group $[18,19]$. Most studies of Ulva marine species have been concerned with the ultrastructure aspects of the rhizoid cell morphology [20], the mitosis process [21], the zoospores [22] and their flagellar apparatus [19], as well as the chloroplast lamellar system [23]. The ultrastructure of the genus Enteromorpha cell wall was addressed only a few times $[14,18]$, and systematic observation throughout the whole life cycle is still missing. As described by Leonardi and Cáceres [14], during zygote formation in U. flexuosa subsp. pilifera the 19 hours old cell developed - a primary and secondary cell wall, shown at low magnification, and although there was an indication of fibrillar structure, no details could be discerned. In another study focused on marine Ulva flexuosa [24], high $\mathrm{Ca}^{2+}$ concentration resulted in a thickening and smoothing of the cell wall internal layers, increase in the number of starch granules, as well as in dimension and the number of cytoplasmic lipid droplets. It was also evident that in marine Ulva forms the chloroplast occupies the majority of the cell volume. The main purpose of this study was to improve our knowledge of the Ulva flexuosa subsp. pilifera cell wall ultrastructure. In addition, we show differences in the size and arrangement of vegetative cells in dependence of thallus age and occurrence of calcium carbonate precipitates.

\section{Material and methods}

Sporophytes samples of Ulva flexuosa subsp. pilifera (Kütz.) M. J. Wynne were collected in the Malta Reservoir (Fig. 1). This is an artificial reservoir, which was constructed for recreation in 1952 by damming the waters of the Cybina River. The research was carried out in June 2011 when freshwater Ulva was in its optimal ontogenetic phase. The material was directly transferred into laboratory in bottles filled with water from the sampling locality. Identification was mainly based according to Bliding [25], Koeman and van den Hoek [26-28], Blomster et al. [29,30], Brodie et al. [31]. The criteria for description and/ or identification of Ulva flexuosa subsp. pilifera were as follow: (i) the macroscopic morphology of the plants (including colour

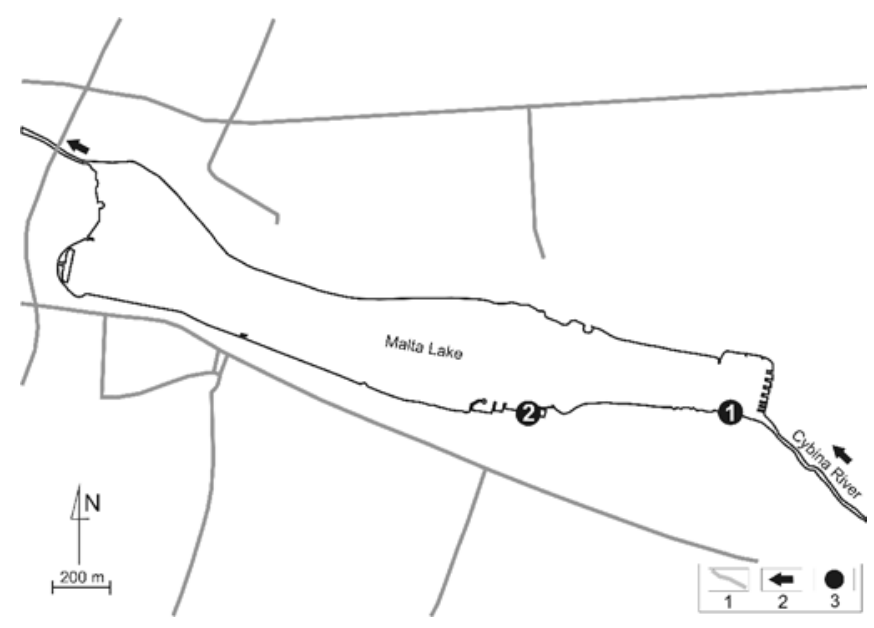

Fig. 1 Collection sites of Ulva flexuosa subsp. pilifera specimens from Poland. and texture); (ii) the structure of the basal region of the axis (and, if present, of branches); (iii) the form and arrangement of the cells in surface view; (iv) the number of pyrenoids per cell; $(\boldsymbol{v})$ the appearance of the chloroplast in surface view; ( $\boldsymbol{v i}$ ) the cell size. For transmission electron microscopy (TEM), cells were fixed as previously described [32]. Ultra-thin sections were cut with glass knives on a Reichert-Jung ultramicrotome (Austria). Observations and photographs were made with a TESLA BS 500 electron microscope. Laboratory analysis included the measurement of thalli (length, width, presence of proliferations) and examination of the morphology of cells (length, width and the size of cells, number of pyrenoids, and the shape and arrangement of cells) with a light microscope $(400 \times)$. All the graphics were prepared with the ProCap software [33]. The basic physico-chemical parameters of the water (temperature, conductivity, concentration of oxygen, $\mathrm{Cl}^{-}$and $\mathrm{pH}$ ) were measured with a YSI Professional Plus handheld multiparameter meter at the sites where Ulva was growing. Samples for our physico-chemical studies were collected in the end of June 2011, whereas Rybak et al. [10] performed the sampling in April and May 17th, 2011.

\section{Results}

In freshwater habitats, and in the Malta Reservoir, the dominant taxon was Ulva flexuosa subsp. pilifera. The material was studied using a combination of classical morphological methods and ultrastructural techniques. No significant difference was observed in the size of Ulva thalli between young and mature (ready for sporulation/gametogenesis) specimens. The water parameters such as depth, $\mathrm{pH}$, electrolytic conductivity, oxygen concentration, and average concentrations of $\mathrm{NO}^{3-}, \mathrm{NH}^{4+}$, $\mathrm{P}_{-} \mathrm{PO}_{4}{ }^{3-}, \mathrm{PO}_{4}^{3-}, \mathrm{NaCl}$ and $\mathrm{Cl}^{-}$are shown in Tab. 1 .

\section{Light microscopy}

In the present study, thalli of Ulva flexuosa subsp. pilifera taken from the surface of the Malta Reservoir on 16 June 2011 were varied in size and had many proliferations. Thalli of the submerged specimens (young thalli) were from 10.1 to 65.1 $\mathrm{cm}$ long and $0.2-1.5 \mathrm{~cm}$ wide. Free-floating thalli (mature and dying thalli) were from 14.9 to $55.1 \mathrm{~cm}$ long and $0.5-2.0 \mathrm{~cm}$ wide (Tab. 1). Neither gametes nor zooids were observed in our material. Vegetative cells contained one parietal, perforated chloroplast with pyrenoids and transverse cell walls without plasmodesmata. In the case of cell measurements, all material was divided into young and mature thalli groups and analyzed separately. These measurements showed that in young thalli rectangular cells were in the range of $32-56 \times 20-35 \mu \mathrm{m}$ and they formed clear longitudinal rows (Fig. 2, Tab. 2). While in mature thalli, the cells were less regular in shape $25-48 \times 19-31$ $\mu \mathrm{m}$, and the rows were not as distinct as those in young thalli. An interesting finding was the presence of numerous calcium carbonate crystals on the surface of the mature thalli cells. Cells of the Ulva flexuosa subsp. pilifera thalli were arranged in longitudinal and transverse rows. The cells in the specimens collected from a pond in sampling site Kuciny were slightly narrower (the lower limits of the width range) compared to cells of thalli from other localities. Chloroplasts in Ulva flexuosa subsp. pilifera cells, from the Malta Reservoir were similar to the thalli described from other freshwater sites, and contained up to four pyrenoids. In our study of Ulva flexuosa subsp. pilifera thalli from the freshwater reservoir, pyrenoids 
Tab. 1 Morphometry of Ulva flexuosa subsp. pilifera thalli and cells from the Malta Reservoir.

\begin{tabular}{|c|c|c|c|c|c|c|}
\hline & \multicolumn{2}{|c|}{ All thalli $(n=120)$} & \multicolumn{2}{|c|}{ Young thalli $(n=60)$} & \multicolumn{2}{|c|}{ Mature thalli $(n=60)$} \\
\hline & $\begin{array}{l}\text { Lenght of thalli } \\
(\mathrm{cm})\end{array}$ & $\begin{array}{l}\text { Width of thalli } \\
(\mathrm{cm})\end{array}$ & $\begin{array}{l}\text { Lenght of cells } \\
\qquad(\mu \mathrm{m})\end{array}$ & $\begin{array}{c}\text { Width of cells } \\
\qquad(\mu \mathrm{m})\end{array}$ & $\begin{array}{l}\text { Lenght of cells } \\
\qquad(\mu \mathrm{m})\end{array}$ & $\begin{array}{l}\text { Width of cells } \\
\qquad(\mu \mathrm{m})\end{array}$ \\
\hline Minimum & 10.10 & 0.20 & 32.21 & 20.24 & 25.09 & 18.90 \\
\hline Maximum & 65.10 & 2.00 & 55.81 & 35.12 & 47.66 & 31.56 \\
\hline Average & 29.09 & 0.72 & 41.99 & 26.40 & 35.89 & 24.66 \\
\hline Standard deviation & 10.42 & 0.42 & 6.06 & 3.94 & 5.01 & 3.55 \\
\hline
\end{tabular}

in the upper parts were more distinct than those in the lower (basal) part. The young cells are thinner compared to mature cells, therefore their structural feature, in particular pyrenoids, are easier to focus on.

\section{Electron microscopy}

The cell walls were multilayered and had a complex structure (Fig. 3, Fig. 4). The transverse sections of the outer cell wall showed from three to six distinct layers enclosed by common wall layers. Each layer was composed of highly irregular electron dense fibrillar network, and limited by thick electron dense lines. These layers were of variable thickness, and in most cases were parallel to each other. The inner cell wall layer, and outer cell wall layer were very similar in appearance. Outer cell wall layer was usually thicker than inner cell wall layer, and the structure of both these layers was less distinct and electron dense than (Fig. 5a,b). In the Fig. 3a,d and Fig. 5c,d, bacteria embedded in mucilage either within or outside the cell wall were observed.

\section{Discussion}

Of the five Ulva species, which have been recorded in inland Polish waters, Ulva flexuosa subsp. pilifera is the rarest. Intense development of this species in the Malta Reservoir was correlated with the abundant availability of nutrients in particular $\mathrm{N}$ [9]. These findings were consistent with other studies previously published [5-10]. When Ulva flexuosa subsp. pilifera was observed for the first time in 2009 [9], the highest values of nutrient concentrations in water were twice as high as the values reported in 2011. The nutrients may have an influence on the seasonal fluctuation in size of Ulva specimens collected.

Using morphological and ultrastructural analyses, we identified and examined Ulva flexuosa subsp. pilifera occurring in the Malta Reservoir in Poland. Our results demonstrated the complexity of the ultrastructure of Ulva flexuosa subsp. pilifera cell wall. However, the function of such a thick cell wall structure is debatable. One possible explanation is that the thick cell wall
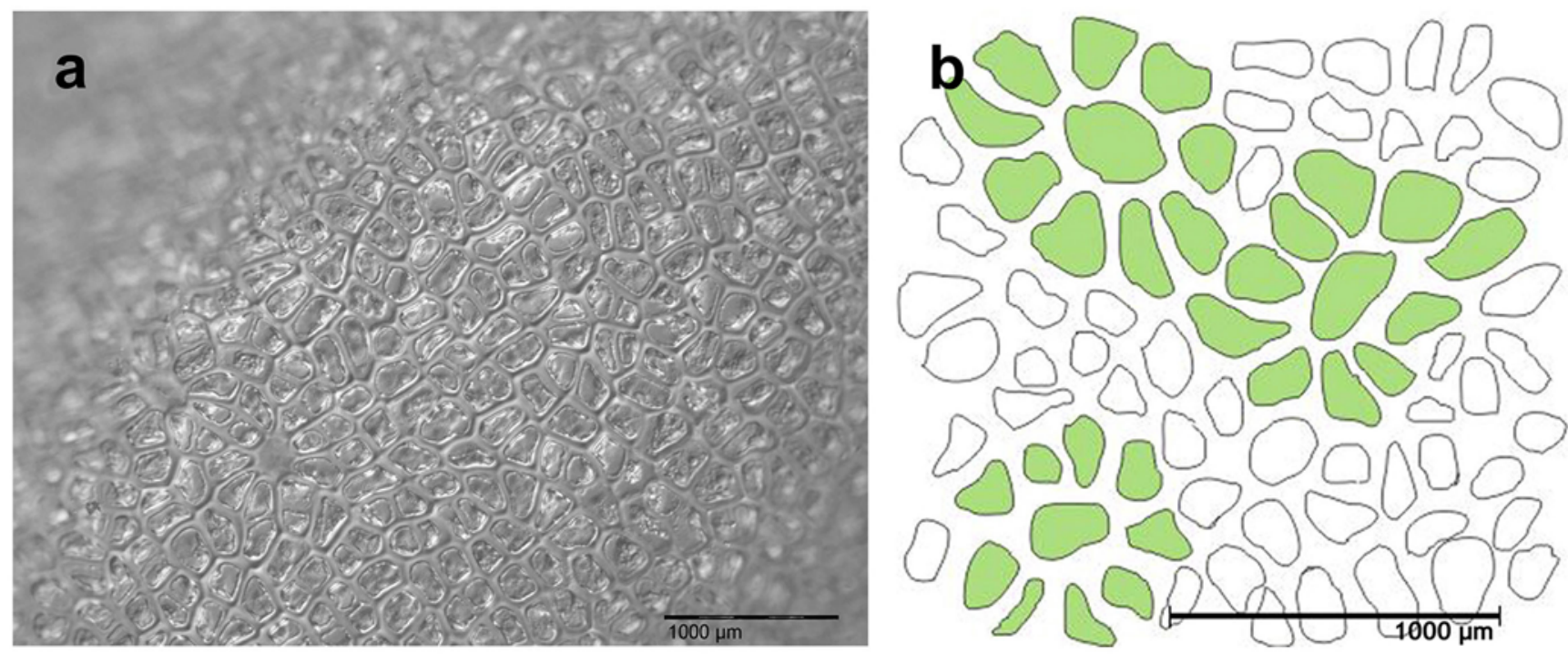

Fig. 2 a Phase contrast light microscopy of mature cells. b Cells radially arranged around crystals in mature thalli of Ulva flexuosa subsp. pilifera.

Tab. 2 Chemical characteristics of the water in the Malta Reservoir (environmental data comes from 2011).

\begin{tabular}{|c|c|c|c|c|c|c|}
\hline \multirow[b]{2}{*}{ Sampling site } & \multicolumn{6}{|c|}{ Factors $\left(\mathrm{mg} \mathrm{l}^{-1}\right)$} \\
\hline & $\mathrm{N}-\mathrm{NO}_{3}$ & $\mathbf{N}-\mathrm{NH}_{4}$ & $\mathrm{NaCl}$ & $\mathrm{P}^{-\mathrm{PO}_{4}}$ & $\mathbf{P O}_{4}^{-3}$ & $\mathrm{Cl}^{-}$ \\
\hline Malta Reservoir & 0.002 & 0.10 & 120 & 0.10 & 0.03 & 73 \\
\hline
\end{tabular}




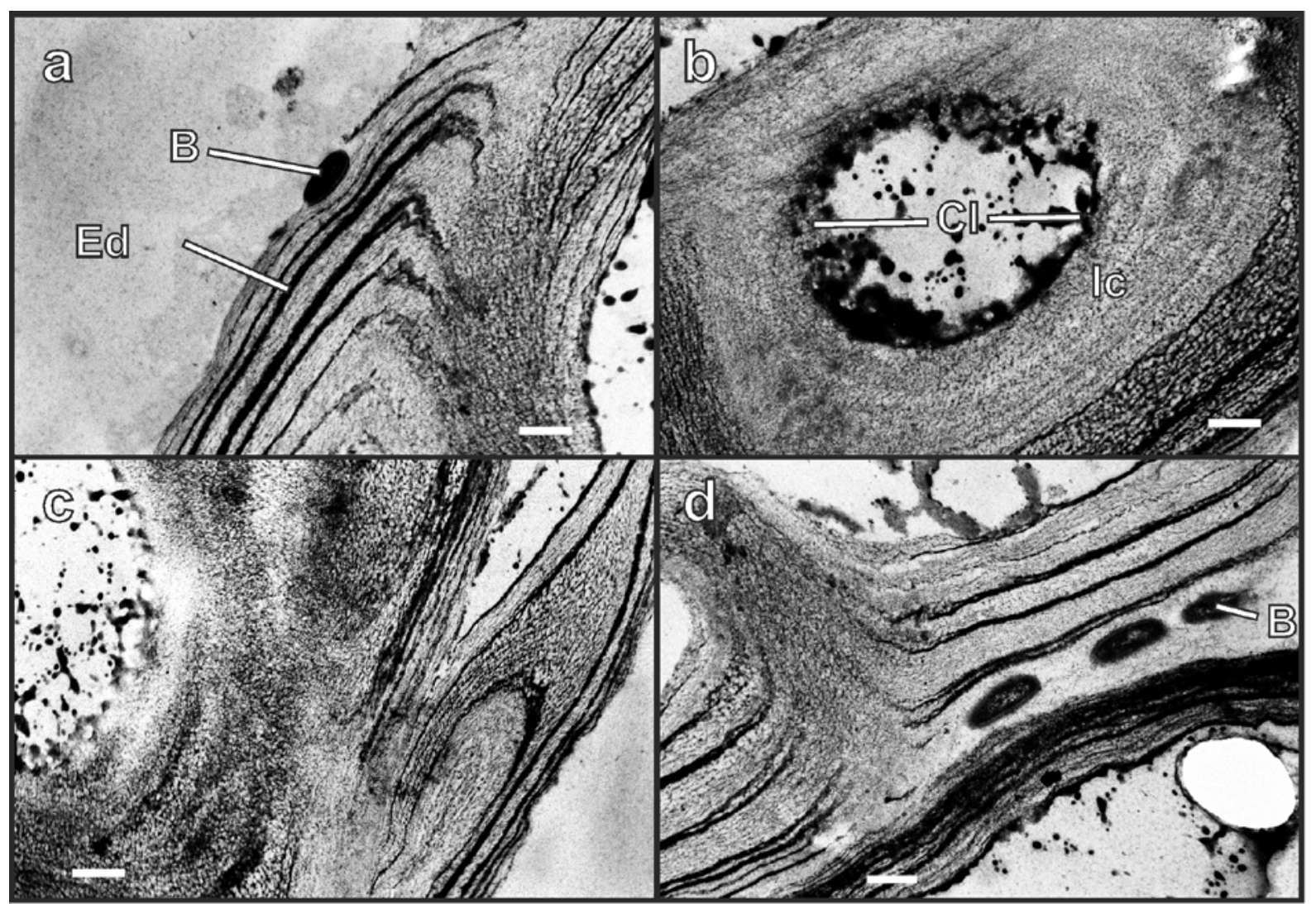

Fig. 3 Transverse and tangential section of Ulva flexuosa subsp. pilifera. a Transverse section of cell wall with bacterium (B) entering cell wall, electron dense material (Ed). b Tangential section of cell wall layers showing the cell lumen $(\mathrm{Cl}$ - inside cell), and appearing more homogenous cell wall fibrillar material. $\mathbf{c}$ Transverse section of cell wall layers displaying part of cell wall in the process of sheding. $\mathbf{d}$ Transverse section of cell wall layers showing bacterial cells (B) deeply inside the cell wall. Scale bars: $10 \mu \mathrm{m}$.

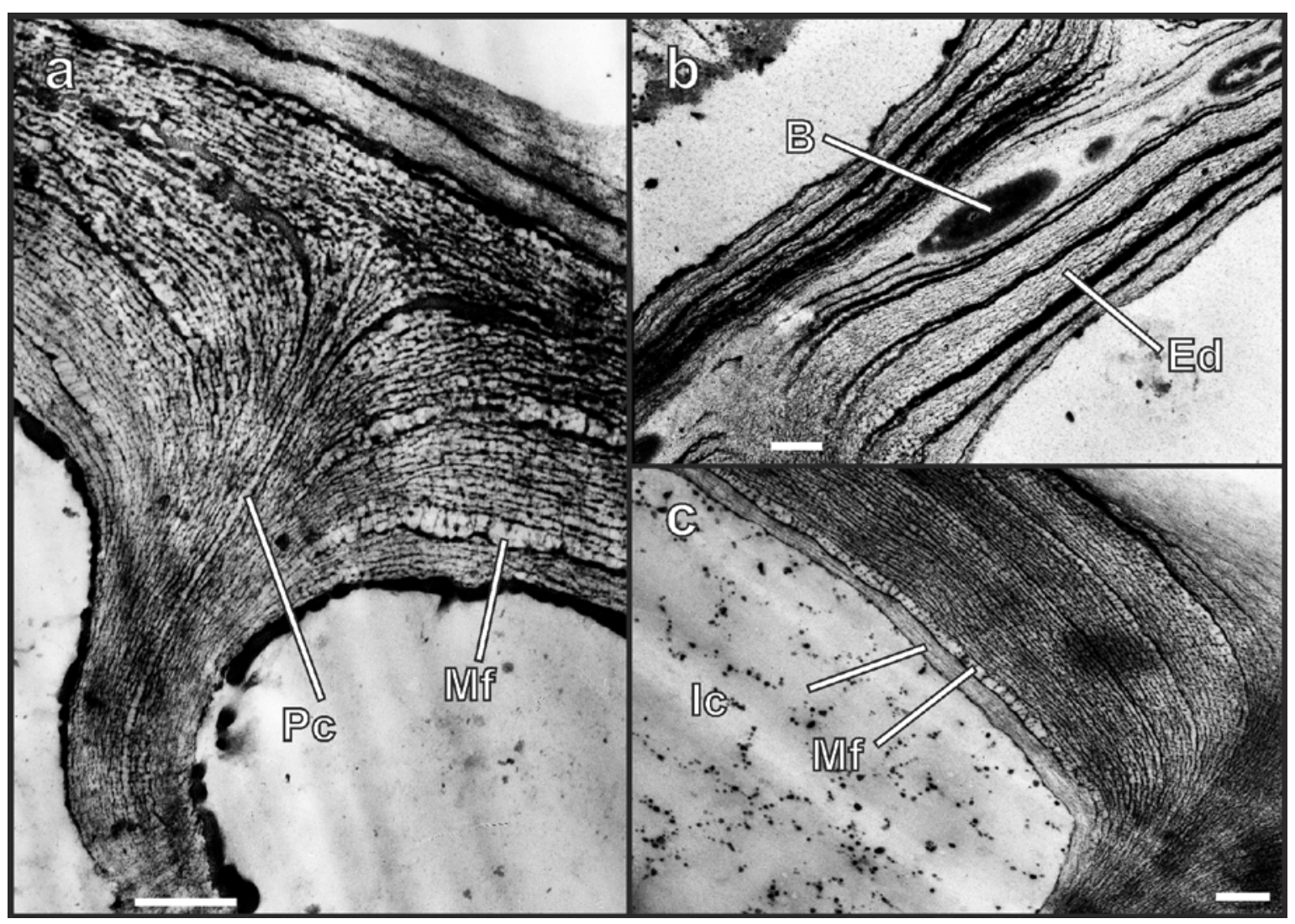

Fig. 4 TEM micrographs of Ulva flexuosa subsp. pilifera. a Transverse section showing primary cell wall (Pc), and details of fibrillar material (Mf). b Transverse section of cell wall layers with bacterium (B) inside the cavity in the cell wall, and the electron dense material (Ed). c Transverse section of inner cell wall layer (Ic), fibrillar material (Mf). Scale bars: $10 \mu \mathrm{m}$. 


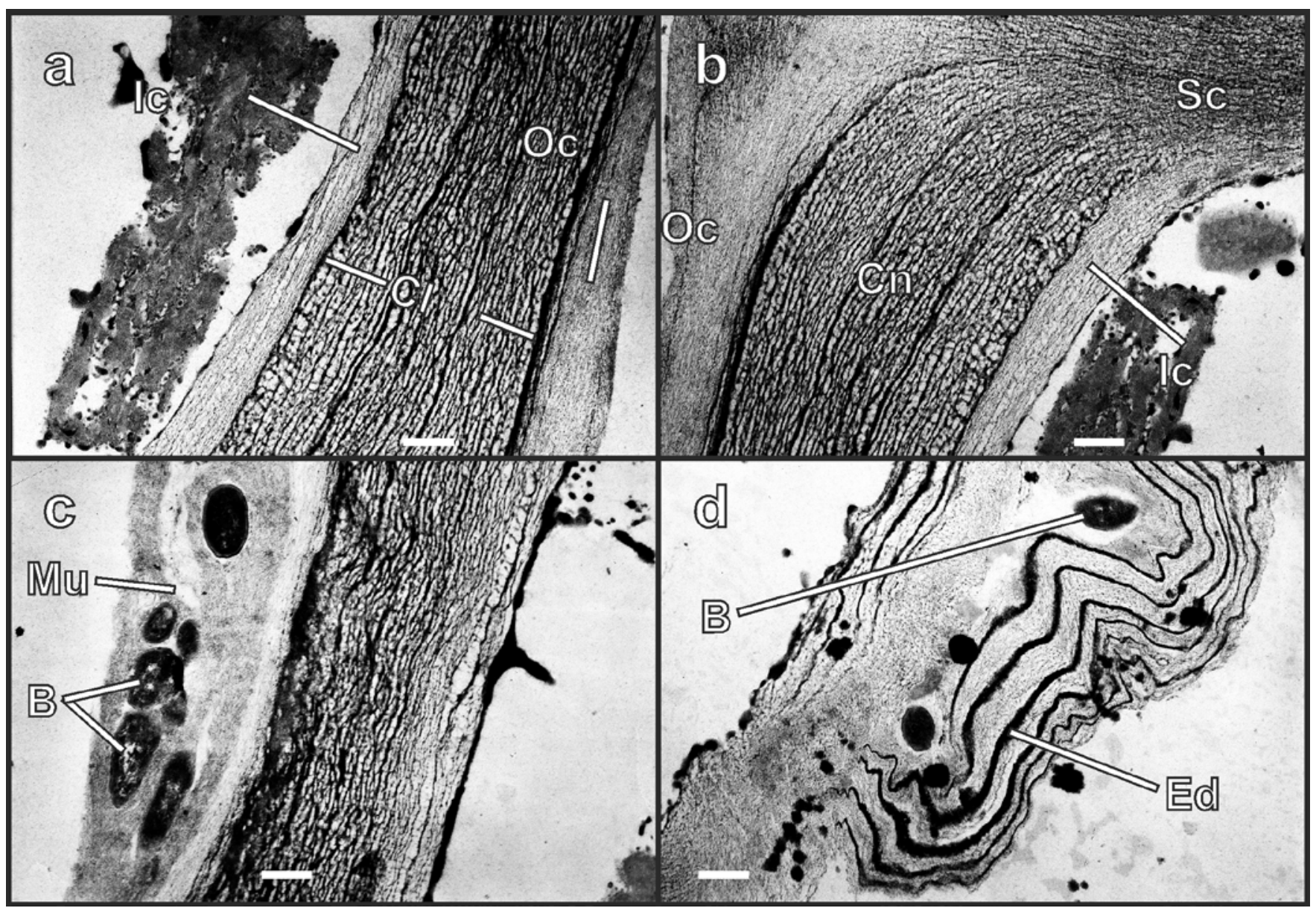

Fig. 5 TEM micrographs of Ulva flexuosa subsp. pilifera. a,b Transverse section of cell wall layers (Cl), the inner cell wall layer (Ic), and outer cell wall layers (Oc). $\mathbf{b}$ Transverse section of the cell wall showing side cell wall (Sc), cell wall network (Cn). $\mathbf{c}$ Transverse section of the cell wall with bacteria (B) embedded in mucilage ( $\mathrm{Mu}$ ) outside the cell. $\mathbf{d}$ Transverse section of the cell wall with bacteria (B) inside the cell wall and the electron dense lines (Ed) which probably delineate the places where the cell wall layers are shed. Scale bars: a-c $5 \mu \mathrm{m} ; \mathbf{d} 10 \mu \mathrm{m}$.

may protect the freshwater macroalga against environmental pollution. Interestingly, abundant calcium carbonate crystals were recorded on older $U$. flexuosa subsp. pilifera thalli. We suggest that the crystals of calcium carbonate forming on the surface of Ulva thalli may have had an influence on the change of cells arrangement. As shown in Fig. 2 and Fig. 6, the cells were often focused radially around the crystals and interjected between longitudinal rows. On the other hand, it was suggested [34] that radially arranged cells can be also found without the presence of crystals. The occurrence of small radially arranged cell clusters has previously been noted as a typical feature of Ulva flexuosa subsp. pilifera mature specimens [13,25]. It may be argued that, the thalli age may correlate with the formation of folds on the thalli surface, as well as with an increase in thalii coarseness, a process that can also involve creation of nonlinearly arranged cell clusters. However, further work on the formation of the large number of calcium carbonate crystals, and their possible effects on cell arrangement, is still required. The fact that the cells from the Malta Reservoir were shorter (at the lower limits of the length range) in comparison to those observed by Sitkowska [7] from the pond in Kuciny, could be related to the varied chemical water composition and/or the availability of nutrient components. The chloroplasts in Ulva cells, from our samples were similar to the chloroplasts in the thalli from other freshwater sites, which have been found by other authors to contain up to four pyrenoids. The number of pyrenoids per cell has been treated as a distinctive feature for identification by Griffiths [17] and Teng et al. [35]. The applicability of this criterion, however, appears to be rather limited on account of the difficulty with which the pyrenoid can be effectively investigated with a light microscope (i.e. the apex cells are usually too small to allow a clear observation of the pyrenoid). Nevertheless, our observation of the pyrenoid number per cell (2-4) in mature thalli of $U$. flexuosa subsp. pilifera appears to be in good agreement with previous studies $[13,25]$.

The ultrastructure of Ulva flexuosa subsp. pilifera cell wall in general showed similarities to the cell wall of Enteromorpha intestinalis [18]. McArthur and Moss [18] studied the early stages of cell wall formation noting the fibrillar material in the small vesicles, and suggested that this material was subsequently used for the cell wall formation. Such vesicles could not be observed in our material, which is most likely because of the fact that the samples contained only adult and/or ageing cells. The layering in the junction between the outside cell wall and the inner cell wall shown in a previous study [18] was also present in our material. Contrary to very regular cell wall stratification with no visible details within the strata as described for the marine species Enteromorpha intestinalis by McArthur and Moss [18], our material revealed highly complex and intricate structures, shown in Fig. 3-Fig. 5. Relatively little information regarding the cell wall chemistry of freshwater Ulvaceae is available, which hinders interpretation of the observed structures. Majority of studies concerning the cell wall of Ulvaceae refer to marine 

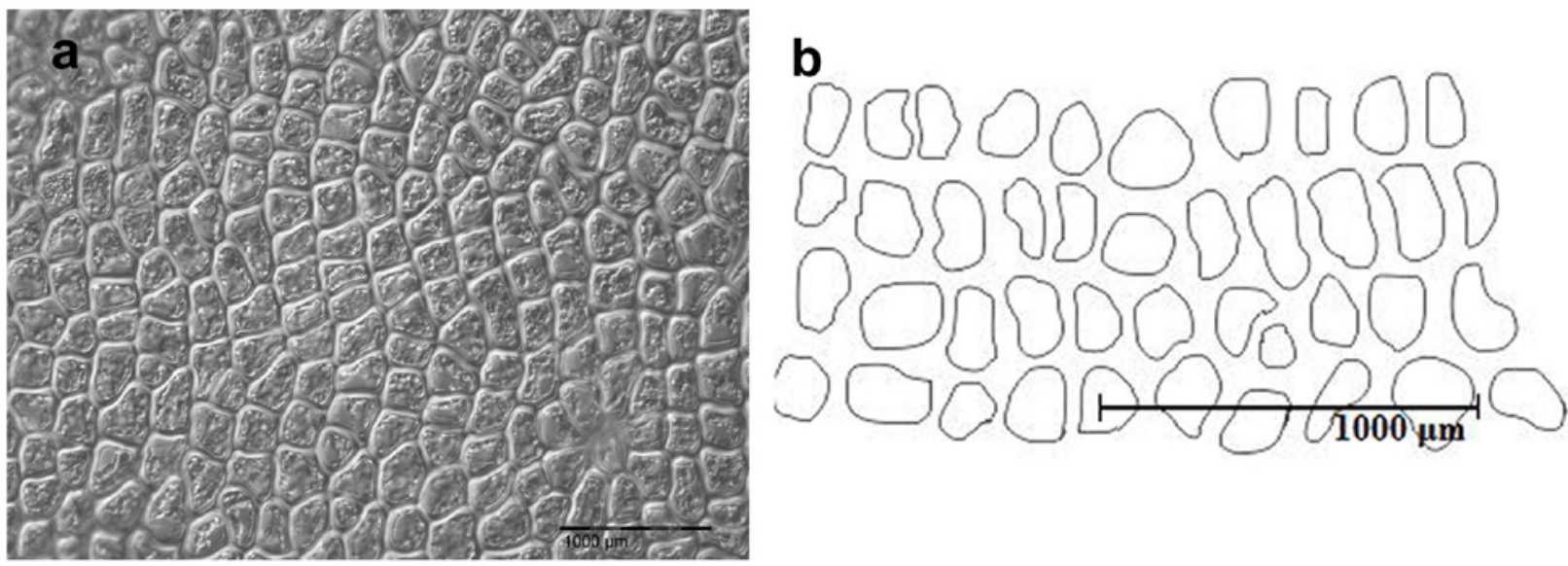

Fig. 6 a Phase contrast light microscopy of young cells arranged in longitudinal rows of Ulva flexuosa subsp. pilifera. b Regular cells arrangement shown with the graphic software Pro-Pro.

habitats. The chemical composition and structure of the glucan in the alkali-insoluble cell-wall polysaccharides from the marine green seaweed Ulva lactuca includes: $\alpha$-cellulose composed of glucose, xylose, rhamnose, uronic acid, and sulfate. The last three components do not appear to be part of the glucan as they were partially removed by methylmorpholine $\mathrm{N}$-oxide treatment [36]. The chemical composition of the freshwater $U$. flexuosa subsp. pilifera cell wall is yet to be determined.

Waite and Mitchell [37] suggested that there is an apparent close benevolent relationship between Ulva and its surface microflora, although an antagonistic bacterial population also exists on Ulva surfaces. These bacteria were found to be capable of degrading Ulva cell walls, and invading the plant cells. Waite and Mitchell [37] also postulated that the antagonistic bacterial population is opportunistic and proliferates when the plant is placed under stress. These findings are in agreement with our observations, in which the bacteria were found both on the cell wall surface, and inside the cell wall between the stratification lines. Spoerner et al. [38] studied the morphology of U. mutabilis depending on its microbial flora. Certain isolated bacterial species recovered in combination the morphogenesis of axenic algal cultures (callus-like morphotype) mediated by specific regulatory factors excreted. Spoerner et al. [38] argues that some of those beneficiary bacteria might be located in the cell wall as well. However, each isolated bacterium alone induced the development of Ulva into thalli composed of cells with characteristic deficiencies. Matsuo et al. [39] isolated, (from an epiphytic marine bacterium), and characterized a causative factor for the induction of normal thallus germination and morphogenesis. Lahaye and Ray [40] found the sugar sequences in the water soluble polysaccharides from Ulvaceae, also Ray and Lahaye [41] as well as Robic et al. [42] studied the cell wall polysaccharides of this group using mid-infrared spectroscopy combined with chemometric techniques.

Our results present the cell wall ultrastructure in more details than so far published by other investigators. Although we did not study the cell wall chemistry, the high complexity and structural details well corresponds with the cell wall multi ingredients composition, confirmed by other authors. The fact that Ulva flexuosa subsp. pilifera exists both in freshwater and marine environment, implies high ecological plasticity of this species. Therefore it would be of interest to continue studies on its ultrastructure.

\section{Acknowledgments}

We are grateful to Prof. Elliot Schubert (Natural History Museum, London, England) for helpful comments and critical reading of manuscript. Prof. Beata Zagórska-Marek (University of Wrocław) for advice on previous draft of this paper. We are also indebted to both anonymous reviewers for their valuable comments that significantly improved the submitted manuscript. The project was supported by funding from the Polish Ministry of Science, grant No. NN 304013437 and partially funded by the project GDWB-07/ 2011.

\section{Authors' contributions}

The following declarations about author's contributions to the research have been made: wrote the paper: JCM, BM, BU; field research: AR, LS, MP; electron microscope analysis: JCM, AM; english verification: JCM, BM, BU.

\section{References}

1. van den Hoek C, Mann DG, Jahns HM. Algae: an introduction to phycology. Cambridge: Cambridge University Press; 1996.

2. John D. Filamentous and plantlike green algae. In: Wehr JD, Sheath R, editors. Freshwater algae of North America: ecology and classification. San Diego CA: Academic Press; 2003. p. 311-349.

3. Fletcher R. The occurrence of "green tides" - a review. In: Schramm W, Nienhuis PH, editors. Marine benthic vegetation: recent changes and the effects of eutrophication. New York NY: Springer; 1996. p. 7-43.

4. John DM, Whitton B, Brook AJ. The freshwater algal flora of the British Isles: an identification guide to freshwater and terrestrial algae. II. Cambridge: Cambridge University Press; 2011.

5. Mareš J. Combined morphological and molecular approach to the assessment of Ulva (Chlorophyta, Ulvophyceae) in the Czech Republic [Master thesis]. České Budějovice: University of South Bohemia, Faculty of Science; 2009.

6. Kowalski W. Występowanie gatunków morskiej zielenicy Enteromorpha Link (1982) w wodach śródlądowych Pomorza Szczecińskiego. Fragm Flor Geobot. 1975;21:527-536.

7. Sitkowska M. Dwa nowe stanowiska Enteromorpha flexuosa subsp. pilifera (Chlorophyta) w Polsce. Fragm Flor Geobot Ser Pol. 1996;6:301-304. 
8. Messyasz B, Rybak A. The distribution of green algae species from the Ulva genera (syn. Enteromorpha; Chlorophyta) in Polish inland waters. Ocean. Hydrobiol Stud. 2009;38(1):121-138. http://dx.doi.org/10.2478/ v10009-009-0001-0

9. Rybak A, Messyasz B. Błonica oszczepowata Ulva flexuosa subsp. pilifera (Chlorophyta, Ulvophyceae) na nowym słodkowodnym stanowisku w Poznaniu. Chrońmy Przyr Ojcz. 2011;67(2):182-188.

10. Rybak A, Messyasz B, Szendzina L, Pikosz M, Koperski M. A new locality of the freshwater population of Ulva flexuosa subsp. pilifera (Chlorophyta, Ulvophyceae) in Poznań (Wielkopolska). Teka Kom Kszt Środ Przyr Ol Pan. 2011;8:131-144.

11. Bliding C. A critical survey of European taxa in Ulvales, part II. Ulva, Ulvaria, Monostroma, Kornmannia. Bot Not. 1968;121:535-629.

12. Starmach K. Zielenice nitkowate. In: Starmach K, editor. Flora słodkowodna Polski. Warsaw: Polish Scientific Publishers PWN; 1972. p. 155-163.

13. Mareš J, Leskinen E, Sitkowska M, Skácelová O, Blomster J. True identity of the European freshwater Ulva (Chlorophyta, Ulvophyceae) revealed by a combined molecular and morphological approach. J Phycol. 2011;47(5):1177-1192. http://dx.doi.org/10.1111/j.1529-8817.2011.01048.x

14. Leonardi P, Cáceres EJ. Ultrastructure of fresh-water alga Enteromorpha flexuosa ssp. pilifera (Ulvophyceae, Chlorophyta) II. Vegetative structure. Nova Hedwig. 1991;53(3-4):545-552.

15. Whitton BA. Increases in nuisance macro-algae in rivers. Verhandlungen Int Ver Für Theor Angew Limnol. 2000;27:1257-1259.

16. Pliński M. Glony Zatoki Gdańskiej - klucz do oznaczania gatunków, VI: zielenice. Gdańsk: University of Gdansk Publishing House; 1988.

17. Griffiths DJ. The pyrenoid. Bot Rev. 1970;36(1):29-58. http://dx.doi. org/10.1007/BF02859154

18. McArthur DM, Moss BL. The ultrastructure of cell walls in Enteromorpha intestinalis (L.) Link. Br Phycol J. 1977;12(4):359-368. http://dx.doi. org/10.1080/00071617700650381

19. Melkonian M. Structure and significance of cruciate flagellar root systems in green algae: zoospores of Ulva lactuca (Ulvales, Chlorophyceae). Helgoländer Wiss Meeresunters. 1979;32(4):425-435. http://dx.doi. org/10.1007/BF02277986

20. Bråten T. Observations on mechanisms of attachment in the green algaUlva mutabilis Føyn. An ultrastructural and light microscopical study of zygotes and rhizoids. Protoplasma. 1975;84(1-2):161-173. http://dx.doi. org/10.1007/BF02075951

21. Løvlie A, Bråten T. On mitosis in the multicellular alga Ulva mutabilis Føyn. J Cell Sci. 1970;6(1):109-128.

22. Callow ME, Crawford S, Wetherbee R, Taylor K, Finlay JA, Callow JA. Brefeldin A affects adhesion of zoospores of the green alga Enteromorpha. J Exp Bot. 2001;52(360):1409-1415. http://dx.doi.org/10.1093/ jexbot/52.360.1409

23. Bond P, Donkin M, Moate R. The development and evaluation of freezefracture/cytoplasmic maceration for the SEM to investigate algal ultrastructure. Micron. 1997;28(6):433-438. http://dx.doi.org/10.1016/ S0968-4328(97)00055-3

24. Andrade LR, Farina M, Filho GMA. Effects of copper on Enteromorpha flexuosa (Chlorophyta) in vitro. Ecotoxicol Env Saf. 2004;58(1):117-125. http://dx.doi.org/10.1016/S0147-6513(03)00106-4

25. Bliding C. A critical survey of European taxa in Ulvales. Part 1: Capsosiphon, Percursaria, Blidingia, Enteromorpha. Opera Bot. 1963;8:1-160.

26. Koeman RPT, van den Hoek C. The taxonomy of Enteromorpha Link, 1820, (Chlorophyceae) in The Netherlands. I. The section Enteromorpha.
Arch Hydrobiol Suppl Algol Stud. 1982;32:279-330.

27. Koeman RPT, van den Hoek C. The taxonomy of Enteromorpha Link, 1820, (Chlorophyceae) in The Netherlands. I. The section Proliferae. Cryptogam Algol. 1982;3:37-70.

28. Koeman RPT, van den Hoek C. The taxonomy of Enteromorpha Link, 1820, (Chlorophyceae) in The Netherlands. I. The sections Flexuosae and Clathratae and an addition to the section Proliferae. Cryptogam Algol. 1984;5:21-61.

29. Blomster J, Maggs CA, Stanhope MJ. Molecular and morphological analysis of Enteromorpha intestinalis and E. compressa (Chlorophyta) in the British Isles. J Phycol. 1998;34(2):319-340. http://dx.doi. org/10.1046/j.1529-8817.1998.340319.x

30. Blomster J, Back S, Fewer DP, Kiirikki M, Lehvo A, Maggs CA, et al. Novel morphology in Enteromorpha (Ulvophyceae) forming green tides. Am J Bot. 2002;89(11):1756-1763. http://dx.doi.org/10.3732/ajb.89.11.1756

31. Brodie J, Maggs CA, John DM. The green seaweeds of Britain and Ireland. London: British Phycological Society; 2007.

32. Massalski A, Mrozińska T, Olech M. Lobococcus irregularis (Boye-Pet.) Reisigl var. nov. (Chlorellales, Chlorophyta) from King George Island, South Shetland Islands, Antarctica, and its ultrastructure. Nova Hedwig. 1995;61(1-2):199-206.

33. ProgRes CapturePro 2.77. Jenoptic, Optical systems, Lase \& Material Processing, Industrial metrology, Traffic solutions, Defense \& civil systems. Germany: Business Unit Digital Imaging; 2010.

34. Leonardi P, Correa JA, Cáceres EJ. Ultrastructure and taxonomy of the genus Endophyton (Ulvales, Ulvophyceae). Eur J Phycol. 1997;32(2):175183. http://dx.doi.org/10.1080/09670269710001737109

35. Teng L, Ding L, Lu Q. Microscopic observation of pyrenoids in order Ulvales (Chlorophyta) collected from Qingdao coast. J Ocean Univ China. 2011;10(3):223-228. http://dx.doi.org/10.1007/s11802-011-1777-6

36. Lahaye M, Jegou D, Buleon A. Chemical characteristics of insoluble glucans from the cell wall of the marine green alga Ulva lactuca (L.) Thuret. Carbohydr Res. 1994;262(1):115-125. http://dx.doi. org/10.1016/0008-6215(94)84008-3

37. Waite T, Mitchell R. The effect of nutrient fertilization on the benthic alga Ulva lactuca. Bot. Mar. 1972;15(3):151-156. http://dx.doi.org/10.1515/ botm.1972.15.3.151

38. Spoerner M, Wichard T, Bachhuber T, Stratmann J, Oertel W. Growth and thallus morphogenesis of Ulva mutabilis (Chlorophyta) depends on a combination of two bacterial species excreting regulatory factors. J Phycol. 2012;48(6):1433-1447. http://dx.doi.org/10.1111/j.1529-8817.2012.01231.x

39. Matsuo $Y$, Imagawa $H$, Nishizawa $M$, Shizuri Y. Isolation of an algal morphogenesis inducer from a marine bacterium. Science. 2005;307(5715):15981598. http://dx.doi.org/10.1126/science.1105486

40. Lahaye M, Ray B. Cell-wall polysaccharides from the marine green alga Ulva "rigida" (Ulvales, Chlorophyta) - NMR analysis of ulvan oligosaccharides. Carbohydr Res. 1996;283:161-173. http://dx.doi. org/10.1016/0008-6215(95)00407-6

41. Ray B., Lahaye M. Cell-wall polysaccharides from the marine green alga Ulva "rigida" (Ulvales, Chlorophyta). Extraction and chemical composition. Carbohydr Res. 1995;274:251-261. http://dx.doi. org/10.1016/0008-6215(95)00138-J

42. Robic A, Bertrand D, Morton JF, Lerat Y, Lahaye M. Determination of the chemical composition of ulvan, a cell wall polysaccharide from Ulva spp. (Ulvales, Chlorophyta) by FT-IR and chemometrics. J Appl Phycol. 2008;21(4):451-456. http://dx.doi.org/10.1007/s10811-008-9390-9 